\title{
Altrichthys alelia, a new brooding damselfish (Teleostei, Perciformes, Pomacentridae) from Busuanga Island, Philippines
}

\author{
Giacomo Bernardi', Gary C. Longo ${ }^{1,2}$, T.E. Angela L. Quiros' \\ I Department of Ecology and Evolutionary Biology, University of California Santa Cruz, California, USA \\ 2 Current address: Conservation Biology Division, Northwest Fisheries Science Center, National Marine Fishe- \\ ries Service, National Oceanic and Atmospheric Administration, Seattle, WA, USA
}

Corresponding author: Giacomo Bernardi (bernardi@ucsc.edu)

Academic editor: M. Bichuette | Received 2 February 2017 | Accepted 24 April 2017 | Published 18 May 2017

http://zoobank.org/7DAE6F77-37B1-463E-B8B7-ODFE95975482

Citation: Bernardi G, Longo GC, Quiros TEAL (2017) Altrichthys alelia, a new brooding damselfish (Teleostei, Perciformes, Pomacentridae) from Busuanga Island, Philippines. ZooKeys 675: 45-55. https://doi.org/10.3897/ zookeys.675.12061

\begin{abstract}
A new species of damselfish, Altrichthys alelia sp. $\mathbf{n}$. is described from specimens collected in shallow water (1-8m depth) off Busuanga Island, Palawan Province, Philippines. It differs from the other two species in the genus, $A$. curatus and $A$. azurelineatus, in various features including having golden upper body lacking dark edges of dorsal and caudal fins, higher modal number of tubed lateral line scales, as well as differences in two mitochondrial markers, one nuclear marker, and RAD markers.
\end{abstract}

\section{Keywords}

Apelagic fishes, Acanthochromis, CO1, Control region, RAD markers

\section{Introduction}

The damselfish genus Altrichthys Allen, 1999 includes two species, the azure damselfish, Altrichthys azurelineatus (Fowler \& Bean, 1928), and the guardian damselfish, Altrichthys curatus Allen, 1999, that occur on shallow coral reefs in the Calamian Archipelago, northern Palawan Province, Philippines (Allen 1999, Bernardi 2011, Bernardi et al. 2017). While conducting exploratory dives in the less-studied area of northern

Copyright Giacomo Bernardi et al. This is an open access article distributed under the terms of the Creative Commons Attribution License (CC BY 4.0), which permits unrestricted use, distribution, and reproduction in any medium, provided the original author and source are credited. 


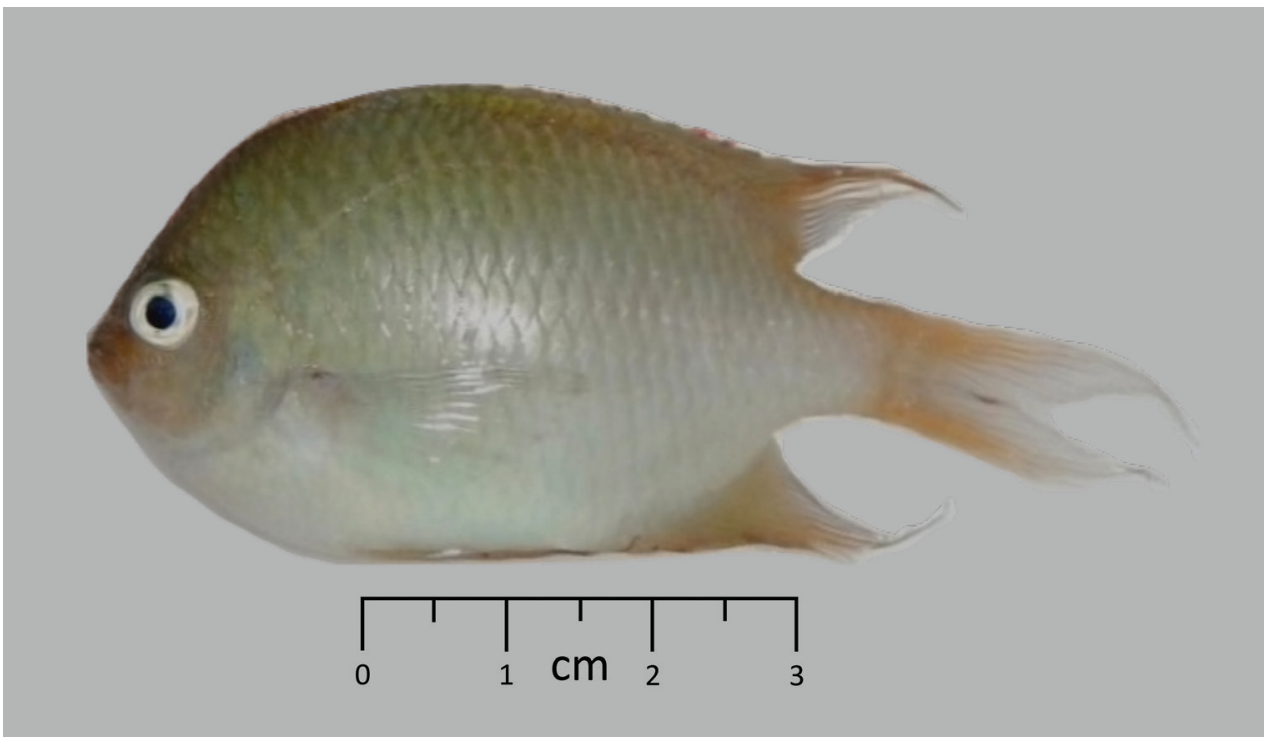

Figure I. Holotype of Altrichthys alelia, shortly after capture. Photo by Gary C. Longo.

Busuanga Island, in the region of San José, we observed and collected Altrichthys individuals that after closer examination and laboratory work showed unique morphological and genetic characters that distinguish them from previously described Altrichthys species. We can therefore confirm the presence of a third Altrichthys species that we hereby describe as the new species Altrichthys alelia (Figure 1).

\section{Methods and materials}

Specimens were collected with hand nets while free or scuba diving in less than $8 \mathrm{~m}$ depth. Counts and measurements follow Allen (1999). Measurements were made days to a few weeks after collection and were taken to the nearest $0.1 \mathrm{~mm}$ with digital calipers. Collection abbreviations are as follows: PNM = National Musem of the Philippines, CAS = California Academy of Sciences.

Fin clip tissue samples were stored in 95\% ethanol and DNA was extracted using DNeasy Blood \& Tissue kits (Qiagen) according to the manufacturer's protocol. DNA was extracted from two Altrichthys alelia individuals (juvenile individuals 6 and 8, in CAS 241439), and from five individuals of each sister species, A. azurelineatus and A. curatus collected at Uson Island and Sangat Island (Figure 2). Extractions were PCR amplified for two mitochondrial (control region and cytochrome oxidase 1) and one nuclear marker (RAG2) following published protocols (Bernardi 2011) (Genbank accession numbers KY963970- KY963994; KY969587, KY969588). Phylogenetic reconstructions were done based on the Neighbor-Joining method 

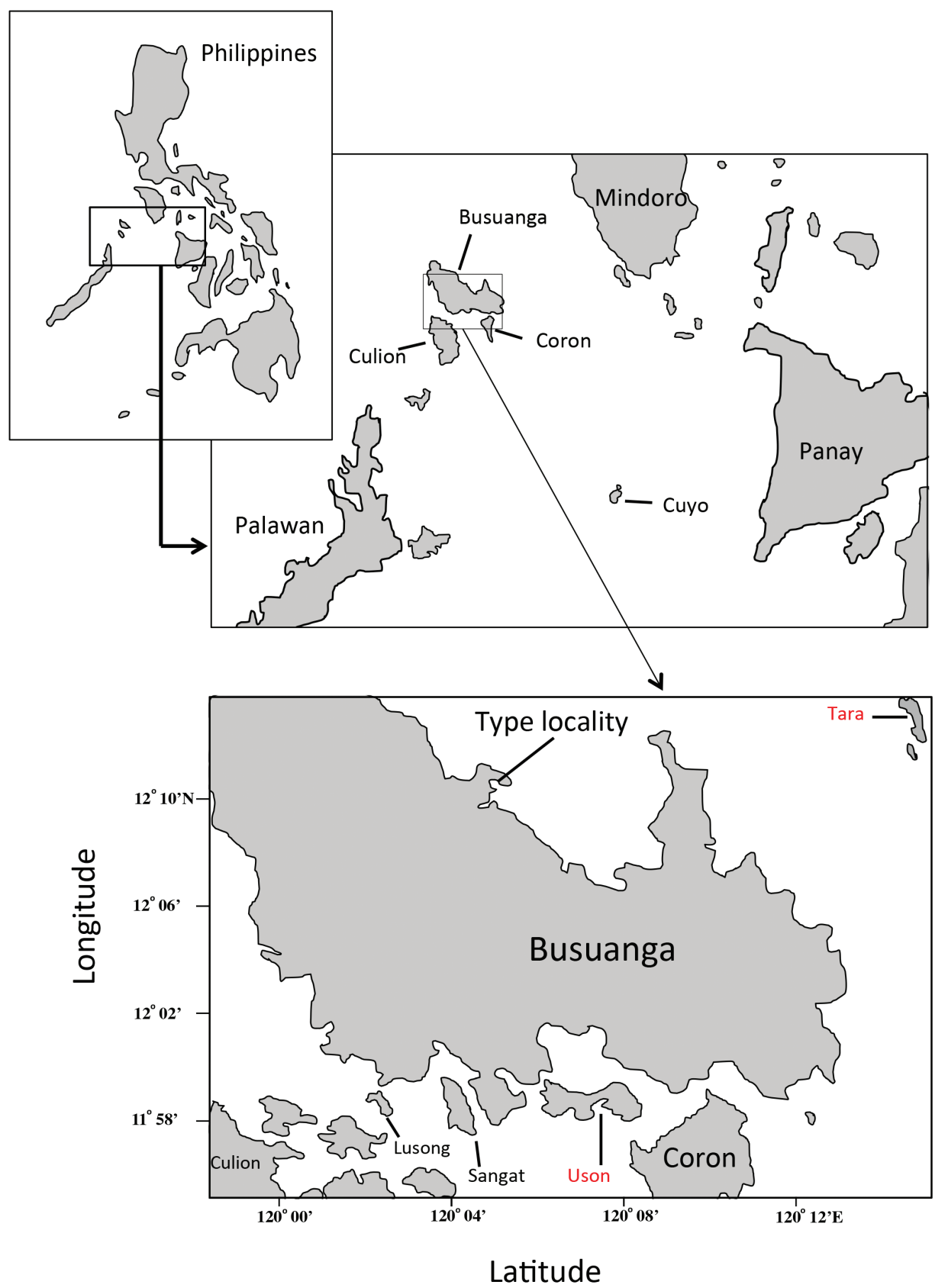

Figure 2. Type locality of Altrichthys alelia. Busuanga Island, Palawan Province, Philippines, near the village of Maricaban, next to the resort "El Rio y Mar", $12.1911^{\circ} \mathrm{N} ; 120.1022^{\circ} \mathrm{E}$. Highlighted in red are Tara Island and Uson Island, where specimens of Altrichthys were first collected, as well as Uson Island and Sangat Island where sister species $A$. azurelineatus and $A$. curatus were collected. 
generated in $\mathrm{R}$ ( $\mathrm{R}$ Core Team 2013) with the ape package (Paradis et al. 2004) using Kimura-2 parameter substitution models, and a Maximum Likelihood method implemented in GARLI (Zwickl 2006). Node support was obtained using 1000 bootstrap replicates and retaining values that support nodes in more than $50 \%$ of the bootstrap replicates.

In addition, we constructed RAD libraries using a variation of the original protocol with restriction enzyme Sbfl (Miller et al. 2007, 2012, Baird et al. 2008, Longo and Bernardi 2015, Omar et al. 2016). Individually barcoded samples were sequenced on an Illumina HiSeq 2500 at the Vincent J. Coates Genomics Sequencing Laboratory at UC Berkeley. Analysis of the sequences followed previously published protocols (Longo and Bernardi 2015).

\section{Taxonomy}

\section{Alelia's damselfish}

Altrichthys alelia Bernardi, Longo, \& Quiros, sp. n. http://zoobank.org/0C9577DE-0F3F-4B27-80F7-9E1B4725212B

Type locality. San José, Busuanga Island, Philippines, $12.1911^{\circ} \mathrm{N} ; 120.1022^{\circ} \mathrm{E}$.

Holotype. PNM 15195; 54.7 mm S.L., San José, Busuanga Island, Philippines, $12.1911^{\circ} \mathrm{N} ; 120.1022^{\circ} \mathrm{E}, 3 \mathrm{~m}$, hand net, G. Bernardi, G. Longo and A. Quiros (Figures 1, 2).

Paratypes. CAS 241438, 3 adult specimens, SL 51.0-54.1 mm; CAS 241439, 8 juvenile individuals, SL $13.9-19.7 \mathrm{~mm}$. Both lots collected with Holotype, Busuanga Island, Philippines, 3m, hand net, G. Bernardi, G. Longo and A. Quiros.

Comparative material. Altrichthys azurelineatus. Holotype: USNM 89957 (one specimen, Uson Island), Paratypes USNM 96398 (one specimen Tara island), USNM 96425 (one specimen, Tara Island). Altrichthys azurelineatus 5 specimens from Uson Island, $A$. curatus 5 specimens from Uson Island and Sangat Island.

Diagnosis and description. A species of Altrichthys distinguished by the following combination of characters: dorsal rays XIV, 13-14; anal rays II, 15, tubed lateral line scales 14-15 (Table 1); preorbital and sensory pores small and numerous, usually more than 30 , adult coloration in life pale green on upper half grading to white on lower part; iris silvery; pale yellow to gold outer margin of dorsal and upper and lower edges of caudal fin. Fins mainly white to translucent. Juveniles up to $16 \mathrm{~mm}$ in length are mostly white with a prominent yellow stripe along the lateral line (Figure 3). Adults are generally of the same size as other Altrichthys adults, approximately $70-80 \mathrm{~mm}$ TL. Altrichthys alelia differs from $A$. curatus by having long filaments at the trailing edges of the dorsal and caudal fins, and from $A$. azurelineatus by lacking any black lining of the outer edges of dorsal and caudal fins. These black margins are represented by yellow/gold margins in A. alelia (Figure 4). Pored lateral 
Table I. Morphometric and Meristic measurements of Altrichthys. Lines present, from top to bottom, numbers for Total Length (TL), Standard Length (SL), Depth, With, Eye Diameter (Eye), spine and ray counts for Dorsal and Anal fins, and Tubed Lateral Line Scales (Tubed LL scales). Number in parenthesis represent percentage of the Standard length). The first column is the species holotype.

\begin{tabular}{l|c|c|c|c}
\hline Voucher number & PNM 15195/ & CAS 241438/ & CAS 241438/ & CAS 241438/ \\
\hline & 9 & 10 & 11 & 12 \\
\hline TL $(\mathrm{mm})$ & 73.6 & 66.8 & 66.2 & 70.2 \\
\hline SL $(\mathrm{mm})$ & 54.9 & 51.6 & 51.0 & 54.1 \\
\hline Depth $(\mathrm{mm})$ & $31.6(57.6 \%)$ & $30.2(58.5 \%)$ & $30.0(58.8 \%)$ & $31.2(57.7 \%)$ \\
\hline Width $(\mathrm{mm})$ & $9.6(17.5 \%)$ & $11.0(21.3 \%)$ & $11.6(22.7 \%)$ & $11.1(20.5 \%)$ \\
\hline Eye $(\mathrm{mm})$ & $5.2(9.5 \%)$ & $5.4(10.5 \%)$ & $5.6(11.0 \%)$ & $5.7(10.5 \%)$ \\
\hline Dorsal fin & XIII, 14 & XIV, 13 & XIV, 13 & XIII, 14 \\
\hline Anal fin & II,15 & II,15 & II,15 & II,15 \\
\hline Tubed LL scales & 15 & 14 & 14 & 15 \\
\hline
\end{tabular}

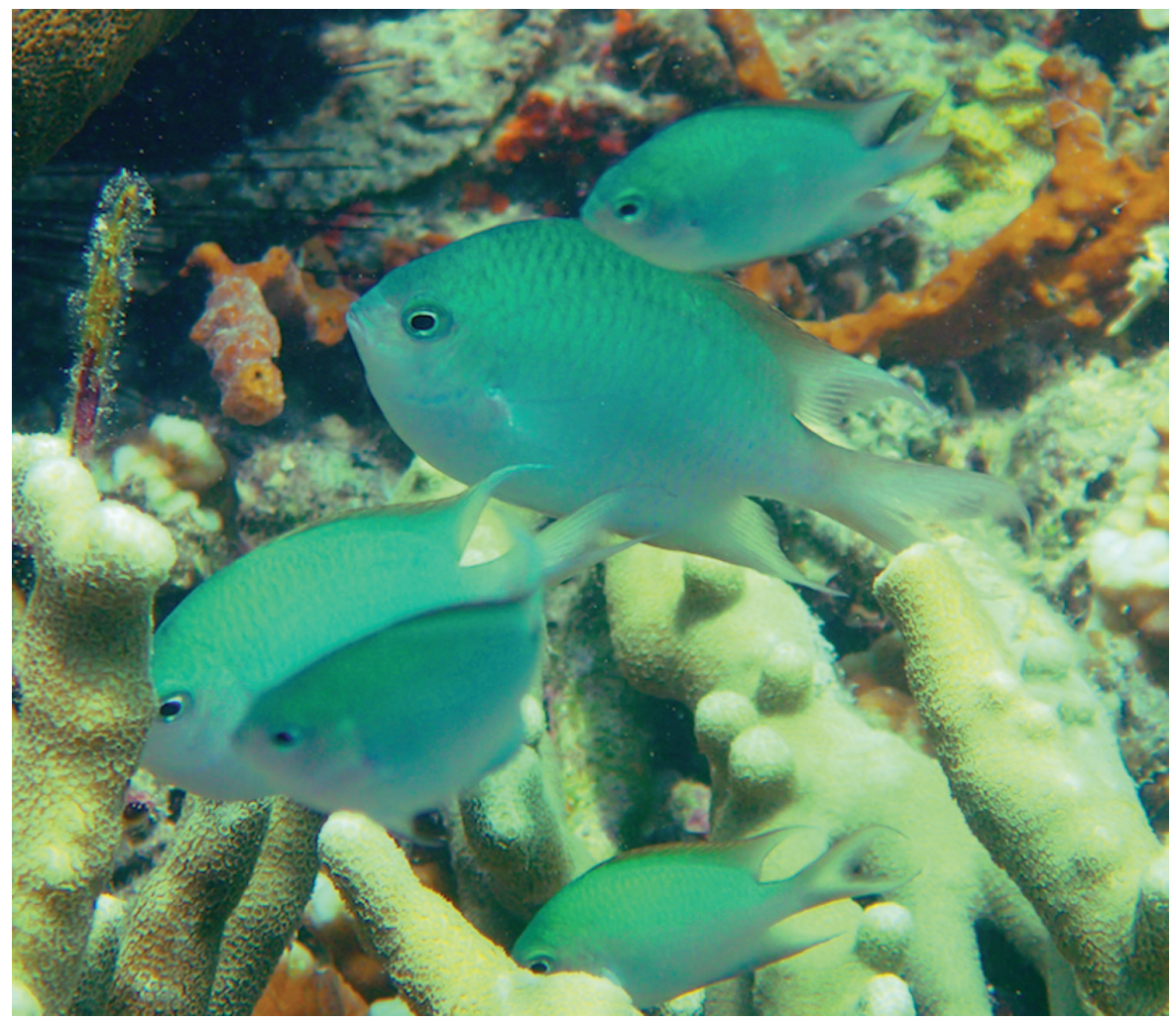

Figure 3. Altrichthys alelia in its natural environment, near a common nesting substrate, the coral Porites cylindrica.

line scales easily distinguish $A$. curatus (17-18) and $A$. azurelineatus (10-14). Counts for $A$. alelia are most similar to and overlap $A$. azurelineatus counts, but exhibit a higher mode (15). 

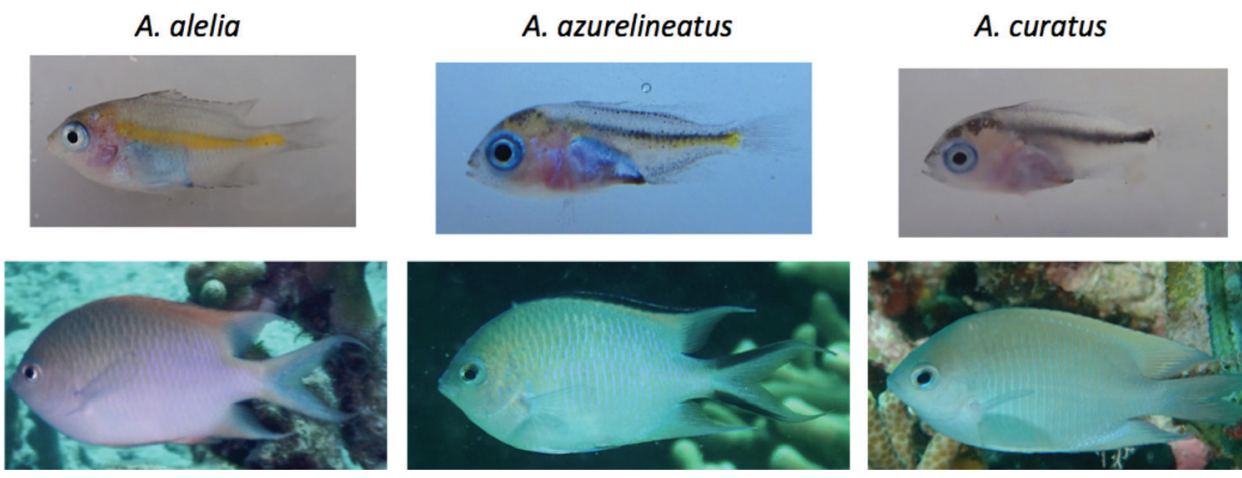

Figure 4. Altrichthys species. Juvenile and adult Altrichthys are shown from left to right: A. alelia, A. azurelineatus, and $A$. curatus. Note the prominent yellow line in the juvenile $A$. alelia, and the lack of black margins in the dorsal and caudal fins in the adult.

Table 2. Results of RAD sequencing in three species. Results are based on 8383 variable SNPs for 5 sequenced individuals ( $2 \mathrm{~A}$. alelia, $1 \mathrm{~A}$. azurelineatus, $2 \mathrm{~A}$. curatus). Figures refer to the number of SNPs and their percentage (over 8383 total SNPs).

\begin{tabular}{l|c|c|c}
\hline & A. alelia & A. azurelineatus & A.curatus \\
\hline A. alelia & $123 / 1.47 \%$ & & \\
\hline A. azurelineatus & $1584.5 / 18.9 \%$ & $-/-$ & \\
\hline A. curatus & $7224.5 / 86.2 \%$ & $6495 / 76.4 \%$ & $8 / 0.0 \%$ \\
\hline
\end{tabular}

In addition, Sanger sequencing results show that Altrichthys alelia individuals form a group most closely related to, but distinct from, A. azurelineatus (Figure 5). Altrichthys alelia sequences differed from their closest relative $A$. azurelineatus by one fixed difference at the nuclear locus RAG2. For mitochondrial markers, Altrichthys alelia sequences differed from $A$. azurelineatus by 13 and 15 fixed mutations for cytochrome oxidase I and control region markers, respectively, thus corresponding to a Kimura-2 sequence divergence of $2.3 \%$ and $5.9 \%$ respectively. These divergences are consistent with values obtained in other sister species of fish (Ward et al. 2005). RAD DNA sequencing results were also consistent with $A$. alelia and $A$. azurelineatus being distinct species and more closely related to each other than either are to A. curatus (Table 2). Indeed, RAD sequencing generated 8383 variable SNPs for the 5 sequenced individuals (2 A. alelia, 1 A. azurelineatus, 2 A. curatus). Of those 8383 SNPs, 1584.5 (18.9\%) showed differences between $A$. alelia and $A$. azurelineatus; while $7224.5(86.2 \%)$ and $6495(76.4 \%)$ showed differences between $A$. curatus and $A$. alelia and between $A$. curatus and $A$. azurelineatus, respectively (Table 2 ).

Distribution. Known from northern Busuanga Island at San José, Palawan Province, Philippines (Figure 2). 

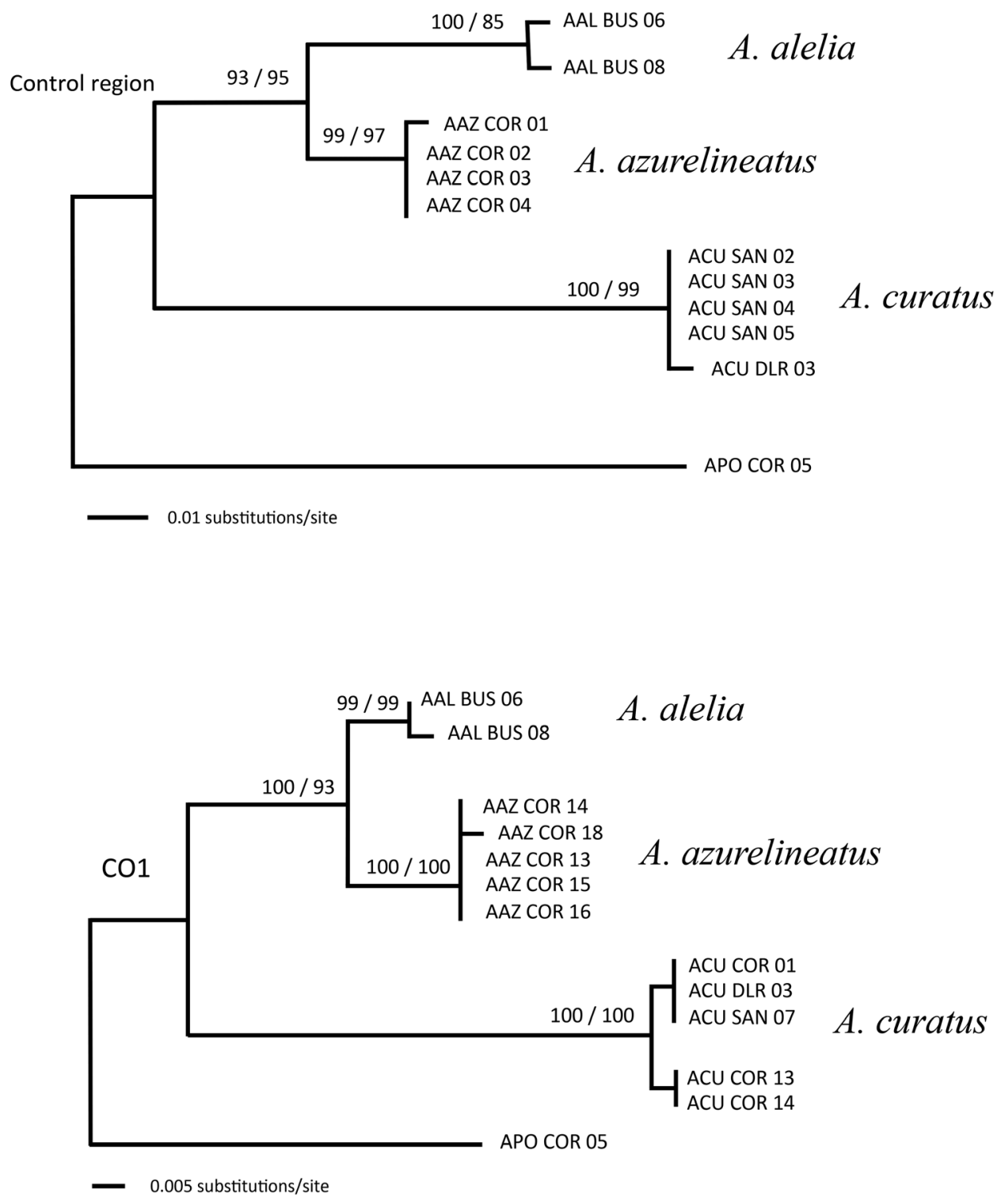

Figure 5. Phylogenetic reconstructions of Altrichthys species based on mitochondrial control region (313 aligned base pairs) and cytochrome oxydase 1 (CO1, 611 aligned base pairs). The closely related Acanthochromis polyacanthus was used as an outgroup. Sample labels refer to collection sites: BUS, El Rio y Mar Resort, Busuanga Island, COR, Balinsasayaw Resort, Uson Island; SAN, Sangat Island; DLR, Dive Link Resort, Uson Island. Numbers above nodes refer to percent of 1000 bootstrap replicates used in NeighborJoining (left) and Maximum Likelihood (right) reconstruction methods. 
Habitat. Collected off live and extensive thickets of corals mostly Porites cylindrica.

Etymology. The name Altrichthys alelia derives from the combined first names of Alessio Bernardi and Amalia Bernardi, who greatly helped during field-work on Altrichthys.

Common name. We suggest Alelia's damselfish as a literal translation of the scientific name.

\section{Discussion}

Species of the genus Altrichthys together with their close relative Acanthochromis polyacanthus are unusual as they brood their young (Allen 1999, Bernardi et al. 2017), whereas most coral reef fishes have a pelagic larval stage (Leis 1991). This behavior is clearly visible on the reef, by the presence of pairs of adult fish aggressively defending a cloud of fry that remain around the parents. An identical behavior was observed in $A$. alelia, where fry and adult pairs were associated, and similarly to the other Altrichthys species, Porites cylindrica is used as a nesting substrate (Bernardi et al. 2017). While Altrichthys azurelineatus and A. curatus co-occur at most locations in southern Busuanga, we did not observe any other Altrichthys species occurring in the vicinity of $A$. alelia.

Altrichthys alelia may have been observed previously by other scientists, but remained unnoticed. The original description of Chromis azurelineatus (Fowler \& Bean, 1928), later re-described as Altrichthys azurelineatus (Allen, 1999), was based on fish collected during the Albatross expedition of 1908-1909. Three collections were made in December 1908 (Smith and Williams 1999). The collection that yielded the type specimen was made in Uson Island, using dynamite. The authors spent several days on Uson Island, and observed hundreds of $A$. azurelineatus there but never saw $A$. alelia in that locality. That specimen indeed looks like a genuine $A$. azurelineatus with its distinctive dark caudal fin margins (USNM, 89957, Figure 6, top right panel). The other collections of the Albatross were at Tara island, which faces the north-eastern portion $\mathrm{Bu}$ suanga Island, a region close to the type locality of $A$. alelia (Figure 2). Fish collected at Tara island have "dorsal spines bright orange, color carried somewhat into membranes in another portion of the fin" (Fowler and Bean 1928). The geographic location and description are consistent with $A$. alelia, however the lack of diagnostic morphological and meristic characters precludes final determination if this were the case. Nevertheless, specimens from these collections lack the characteristic black margins on the caudal fin that is found in A. azurelineatus (USNM, 96398, and USNM, 96425, Figure 6, bottom left and bottm right panels). The drawing of $A$. azurelineatus in the original description by Fowler and Bean (1928), and later redrawn in color (Allen 1991), does not show the dark margins either (Figure 6, top left panel), as it may have been a compilation of all the various specimens collected (i.e. a combination of $A$. azurelineatus and $A$. alelia individuals). As such, that drawing is more similar to $A$. alelia. Finally, the picture taken on Busuanga island labeled as A. curatus in Figure 2 of Allen (1999), looks precisely like A. alelia. Due to the peculiarities of this fish, Allen (1999) suggested that "additional observations are needed", which is what we are presenting here. 

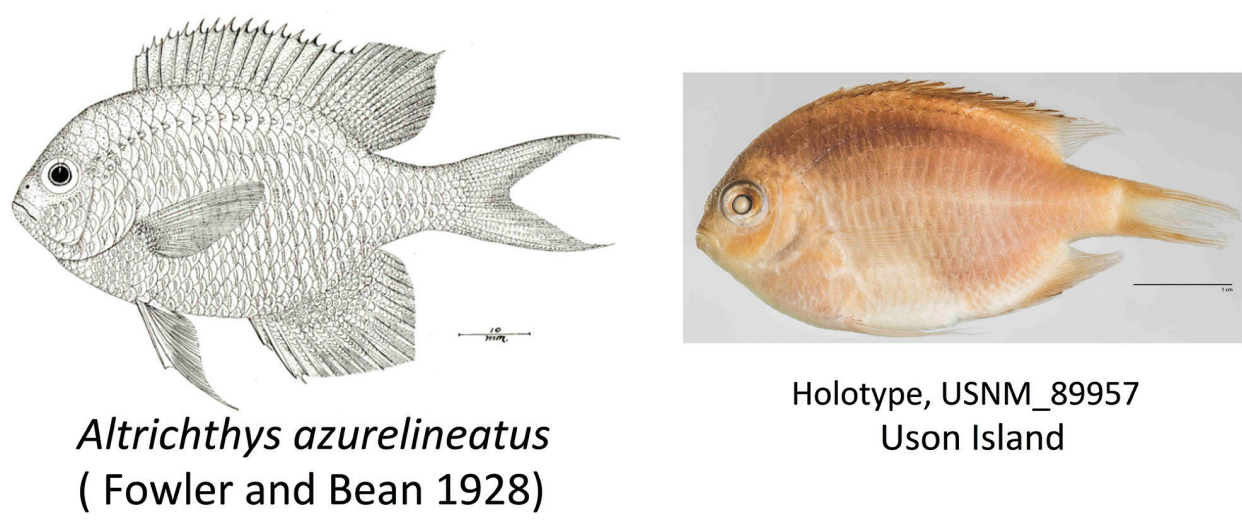

Holotype, USNM_89957 Uson Island

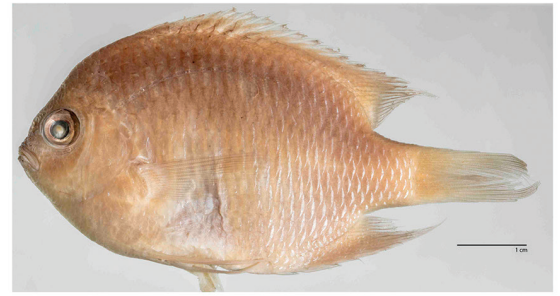

Paratype, USNM_96398

Tara Island

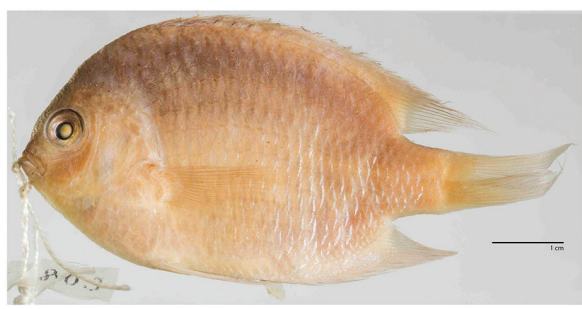

Paratype, USNM_96425

Tara Island

Figure 6. Drawing (upper left, from Fowler and Bean 1928) and photo (upper right) of the holotype of Altrichthys azurelineatus from Uson Island (USNM 89957), and paratypes (bottom photos) (USNM 96398, 96425) collected at Tara Island. Photos by Sandra J. Raredon, Division of Fishes, Smithsonian Institution.

\section{Acknowledgments}

We would like to thank Nicole Crane, Amalia Bernardi, and Alessio Bernardi for help in the field. We thank the following: Bureau of Fisheries and Aquatic Resources (Commodity Clearance 2016-20091), Palawan Council for Sustainable Development (PCSD, GP 2016-03, Wildlife Transport Permit No. 2016-05-000062-DMO - Calamianes, Fisheries inspection and quarantine clearance Permit no. 009391) and Leonora Labrador and Eva Palanca of the Coron PCSD office. Ateneo de Manila University's Hendrik Freitag, Merab A. Chan, Jonathan Patrick H. Yan for the Memorandum of Agreement between UCSC and the Department of Biology at Ateneo de Manila. Busuanga Mayor (Samuel de Jesus) and Councilor (Ann D. Mercado), Coron Mayor (Clara Espiritu-Reyes) and Samuel Madamba, Culion Mayor (Emiliano Marasigan) and Councilor Leonilo Sarmiento for Prior Informed Consent (PIC), given in 2015. Hikari South Sea Pearl, Luna Sombrano, Agustin R. Badon II, Eric T. Dalisay, and Pinky Perpetua for assistance in obtaining the PICs. We thank El Rio y Mar Resort, Dive Link Resort, and Balinsasayaw for letting us visit their reefs, and Gerald Allen for 
discussing our data and invaluable information on Altrichthys. We are very grateful to Sandra J. Raredon for taking pictures of Altrichthys specimens at the Smithsonian collection, and to Don Dumale (National Museum of the Philippines) and David Catania (California Academy of Science) for providing Holotype and Paratype numbers. This work was funded by a National Geographic Grant and a UCSC Committee on Research (COR) grant to GB.

\section{References}

Allen GR (1991) Damselfishes of the World. Aquarium Systems, Mentor, Ohio.

Allen GR (1999) Altrichthys, a new genus of damselfish (Pomacentridae) from Philippine seas with description of a new species. Revues Francaise d'Aquariologie 26: 23-28.

Baird NA, Etter PD, Atwood TS, Currey MC, Shiver AL, Lewis ZA, Selker EU, Cresko WA, Johnson EA (2008) Rapid SNP discovery and genetic mapping using sequenced RAD markers. PloS one 3: e3376. https://doi.org/10.1371/journal.pone.0003376

Bernardi G (2011) Monophyletic origin of brood care in damselfishes. Molecular Phylogenetics and Evolution 59: 245-8. https://doi.org/10.1016/j.ympev.2010.12.021

Bernardi G, Crane NL, Longo GC, Quiros AL (2017) The ecology of Altrichthys azurelineatus and $A$. curatus, two damselfishes that lack a pelagic larval phase. Environmental Biology of Fishes 100: 111-120. https://doi.org/10.1007/s10641-016-0559-9

Fowler HW, Bean BA (1928) The fishes of the families Pomacentridae, Labridae, and Callyodontidae, collected by the United States Bureau of Fisheries steamer "Albatross," chiefly in Philippine Seas and adjacent waters. Bulleting of the US National Museum 100: 1-525.

Leis J (1991) The Pelagic Stage of Reef Fishes. In: Sales P (Ed.) The Ecology of Fishes on Coral Reefs. Academic Press Inc., San Diego, CA, 182-229. https://doi.org/10.1016/B978-008-092551-6.50013-1

Longo G, Bernardi G (2015) The evolutionary history of the embiotocid surfperch radiation based on genome-wide RAD sequence data. Molecular Phylogenetics and Evolution 88: 55-63. https://doi.org/10.1016/j.ympev.2015.03.027

Miller MR, Brunelli JP, Wheeler PA, Liu S, Rexroad CE, Palti Y, Doe CQ, Thorgaard GH (2012) A conserved haplotype controls parallel adaptation in geographically distant salmonid populations. Molecular Ecology 21: 237-49. https://doi.org/10.1111/j.1365294X.2011.05305.x

Miller MR, Dunham JP, Amores A, Cresko WA, Johnson EA (2007) Rapid and cost-effective polymorphism identification and genotyping using restriction site associated DNA (RAD) markers. Genome Research 17: 240-8. https://doi.org/10.1101/gr.5681207

Omar AA, O'Rourke SM, Amish SJ, Meek MH, Luikart G, Jeffres C, Miller MR (2016) RAD Capture (Rapture): Flexible and efficient sequence-based genotyping. Genetics 202: 389-400. http://dx.doi.org/10.1101/028837

Paradis E, Claude J, Strimmer K (2004) APE: Analyses of Phylogenetics and Evolution in R language. Bioinformatics 20: 289-290. https://doi.org/10.1093/bioinformatics/btg412 
Smith DG, Williams JT (1999) The Great Albatross Philippine Expedition and Its Fishes. Marine Fisheries Review 61: 31-41.

Team RDC (2013) R: A Language and Environment for Statistical Computing. The R Project for Statistical Computing, Vienna, Austria. www.R-project.org

Ward RD, Zemlak TS, Innes BH, Last PR, Hebert PDN (2005) DNA barcoding Australia's fish species. Philosophical transactions of the Royal Society of London. Series B, Biological sciences 360: 1847-57. https://doi.org/10.1098/rstb.2005.1716

Zwickl DJ (2006) Genetic algorithm approaches for the phylogenetic analysis of large biological sequence datasets under the maximum likelihood criterion. PhD Thesis, Department of Biology, The University of Texas, Austin, 125 pp. http://www.molecularevolution.org/ molevolfiles/garli/zwicklDissertation.pdf 
